This is the peer reviewed version of the following article:

Charbonneau, Johanne, and Sylvie Daigneault. 2016. "Engaging ethnic minority blood donors." ISBT Science Series 11 (S1):140-147. doi: 10.1111/voxs.12203.

which has been published in final form at https://dx.doi.org/10.1111/voxs.12203. This article may be used for noncommercial purposes in accordance with Wiley Terms and Conditions for Self-Archiving." 


\section{Engaging Ethnic Minority Blood Donors}

Revised version accepted for publication in ISBT Science Series

Charbonneau, Johanne ${ }^{1}$, Sylvie Daigneault ${ }^{2}$

${ }^{1}$ Research Chair of Social Aspect of Blood Donation

INRS Urbanisation Culture Société

385 Sherbrooke Street East, Montreal, QC, Canada H2X 1E3

${ }^{2}$ Marketing and International Affairs

Héma-Québec

4045 Côte-Vertu Blvd, St-Laurent, QC, Canada H4R 2W7

Running head: Minority Blood donors

Source of research support: Héma-Québec

Corresponding author:

Johanne Charbonneau

INRS Urbanisation Culture Société

385 Sherbrooke Street East, Montreal, QC, Canada H2X 1E3

Phone: 1514 499-6603

Fax: 1514 499-4065

johanne.charbonneau@ucs.inrs.ca 


\begin{abstract}
Background and Objectives. Targeting ethnic minorities is consistent with the objective of ensuring better access to rare phenotypes. The number of blood donors is generally lower among these groups. This paper seeks to present the solutions Héma-Québec has developed to address this challenge. Materials and Methods. In 2010-2011, the organization conducted 53 awarenessraising activities targeting black communities. In 2009-2010, 83 interviews were conducted with donors and leaders of diverse ethnic groups in Montreal. Employees' perceptions were also explored. Based on research findings, a training seminar was developed and provided to 69 frontline managers. Its most important elements were integrated into basic training for all employees. Results. The number of black community donors climbed from 170 in 2009 to 1,582 in 2012. However, experiences with ethnic associations and donors have raised many concerns among staff. The two-day training helped planning services develop better recruitment strategies and bolster employees' self-confidence with regard to their interactions with ethnic minorities. Conclusion. New strategies are dependent on the specific characteristics of each country's ethnic diversity, the availability of empirical data on minorities, and the clearly expressed will of management in blood products supply organizations.
\end{abstract}

\title{
Keywords
}

Blood donation, ethnic minorities, ethnic diversity, sickle-cell disease, donor recruitment, training program 


\section{Introduction}

In the last years, it has been confirmed that in order to treat certain diseases-such as sickle-cell disease-it is preferable to use phenotypic blood from the same community as the donor in order to reduce risks related to allo-immunization ${ }^{[1-4]}$. Phenotypic incompatibility can lead to the development of antibodies that, in turn, attack red blood cells in subsequent transfusions and lessen the treatment's efficacy. Sickle-cell disease is especially prevalent in populations whose origins lie in sub-Saharan Africa, the Caribbean, India, the Middle East or the Mediterranean ${ }^{[5,6]}$. Targeting immigrants or ethnic minorities with ancestors from these regions is consistent with the objective of ensuring better access to rare phenotypes.

Another problem facing blood collections is the low rate of blood donation in urban settings ${ }^{[7]}$ despite that urban individuals have easier access to blood drives as a result of the latter's more varied locations and schedules. Blood collection agencies therefore have no choice but to take an interest in urban ethnic diversity.

This paper seeks to present the initiatives developed by Héma-Québec over the last five years in order to address these challenges. In 2009, Héma-Québec, the organization responsible for blood product supply in Quebec, Canada, commissioned the INRS Research Chair on Social Aspects of Blood Donation to carry out a research project on the relationship between ethnic groups in Montreal and blood donation. Between March 2009 and May 2010, 83 interviews were conducted with donors and leaders of ethnic groups in Montreal ${ }^{[8]}$. The perceptions held by Héma-Québec employees were also explored. Meanwhile, the organization also conducted 53 awareness-raising activities to recruit new donors from Black communities in order to meet the medical needs of persons affected by sickle-cell disease ${ }^{[9]}$. In 2013, the Research Chair developed a multi-step training program for Héma-Québec's managerial staff in order to help boost employees' confidence when dealing with ethnic donors and planning services to recruit more donors.Situational analysis

An increasingly large proportion of the population in Western countries is foreign-born. Of all G8 ${ }^{1}$ members, Canada is the country with the highest number of foreign-born residents (20\%). According to the 2011 National Household Survey, in the province of Quebec, almost $13 \%$ of the total population is foreign-born. Of these, $87 \%$ live in the Montreal area, where they represent $23 \%$ of the total population ${ }^{[10]}$. The immigrant population in Quebec is more ethnically diverse than in the rest of Canada, where it is largely made up of Asians. It is worth noting that this portrait of Quebec immigrants has changed considerably over the years. Before $1976,68 \%$ percent of

\footnotetext{
${ }^{1}$ USA, United Kingdom, France, Germany, Japan, Russia, Italy and Canada.
} 
Quebec immigrants were from Europe. In the following decade, the West Indies and Bermuda (15\%), along with Southeast Asia (17\%) were the primary countries of origin for most immigrants. Starting in 1986, the Middle East (14\%) took the lead, until 1996, when North Africa (16\%), East Asia (11\%), South America (10\%), and Eastern Europe (12\%) supplied the greatest numbers of immigrants to Quebec ${ }^{[11]}$. Since 2006, the main countries of immigration have been Algeria, Morocco, France, Haiti, China, Colombia, Mexico and the Philippines ${ }^{[12]}$. The proportion of individuals belonging to a visible minority stands at $11 \%$ of the Quebec population, although this group is growing ${ }^{[10]}$. A visible minority is defined by the Canadian government as persons other than aboriginal peoples, who are non-Caucasian in race or non-white in colour. The term is used as a demographic category by Statistics Canada, in connection with Employment Equity policies, to address the labour market disadvantage of this group. Blacks (28.7\%), Asians (including Chinese, South Asian, Southeast Asian, West Asian, Korean, and Japanese - 28.5\%) Arabs (19.6\%), and Latin Americans (13.7\%) represented the main visible minorities in Quebec. In the Greater Montreal Area, $20 \%$ of the population currently belongs to a visible minority.

These data reflects Quebec's unique ethnic composition, which differs from that of many other regions and countries. This is why it is important to stress from the outset that there is no single correct way to recruit donors from ethnic groups. Each country's distinctive ethnic composition must first be taken into account. Questions such as the following could provide some of the information that would help illustrate each country's ethnic diversity: Is there a single dominant ethnic group, or two? Have ethnic groups been in the country for decades, or are they more recent and made up of first-generation immigrants? Does the migration profile frequently change? It goes without saying that recruitment tactics used would have to depend on the reality presented by each country.

The number of donors is generally lower among persons from minority ethnic groups than in the majority population ${ }^{[13-16]}$. For example, in the United States, African American donors represent 6.5 percent of the total blood pool donor, while African American account for 13 percent of the population $^{[3]}$. In Quebec, 90.8\% percent of blood donors in 2014-2015 were Whites, 1.3\% Arabs, $0.7 \%$ Latin Americans, and $0.5 \%$ Blacks. Yet, Blacks account for 3.2\% of the population of Quebec (Latin Americans, 1.5\%, and Arabs 2.2\%). The most frequently cited obstacles are related to the following:

- High rates of refusal in certain communities (medical reasons) ${ }^{[4,17]}$; 
- Lack of information about systems, rules, and procedures ${ }^{[18,19] \text {; }}$

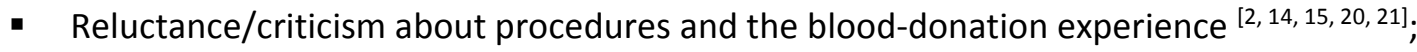

- Lack of satisfactory forms of recognition in the volunteer system ${ }^{[13]}$;

- Problems regarding economic and social integration ${ }^{[19,22]}$;

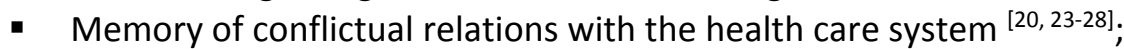

- Fear of contamination risks ${ }^{[2]}$;

- Cultural references not conducive to donation between strangers ${ }^{\text {[29-35]; }}$

- Cultural or religious attitudes about blood and reluctance of the organization to take these attitudes into account ${ }^{[18,36]}$.

Interest in these issues has been slow to develop. In the United States, there has been some fragmented progress in strategies targeting Black and Latin American minorities ${ }^{[37]}$. In Europe, the situation varies widely from one country to the next ${ }^{[38]}$.

Each country has its own specific way of addressing ethnic and cultural diversity [39, 40]._-it structures public debate, informs state policies and programs, and fuels private citizens' perceptions. Policies play a central role insofar as they define the way in which a society recognizes, or fails to recognize, the existence of groups that may differ (from one another and from the majority group) in terms of their history, values, and perceptions of their own integration into the society.

These differences are precisely what influence minority groups' attitudes towards blood donation ${ }^{[8]}$. Their histories provide information on their confidence in the health care system and their familiarity with the blood donation system. Their values provide insight into cultural and religious attitudes towards blood, and the main forms of social solidarity (donating) traditionally found in their communities. Ethnic groups' perceptions of their integration into society are important because blood donation is a form of civic participation, and the blood collection system is an institution that is representative of the majority population ${ }^{[41]}$.

On a more pragmatic level, one of the most important things is that each country's specific way of addressing ethnic diversity issues affects the ability to access empirical data concerning these groups. Such data are vital to develop a program aimed at improving the recruitment and retention of donors from ethnic minorities. The initiatives taken in Quebec in the last few years have relied on:

- Census statistics on socio-demographical characteristics of immigration and minority populations in Quebec;

- Analysis of the geographical distribution of the main immigration groups and ethnic minorities; 
- A qualitative study on blood donation and ethnic minorities in Quebec;

- Sociological case studies of different ethnic minorities in Montreal;

- Results of consultations with Héma-Québec staff; and

- Statistical data on blood donors.

Since 2009, blood donors in Quebec have been asked to voluntarily answer a question indicating whether they belong to an ethnic minority. This provides a better understanding of their blooddrive-attendance habits and makes it easier to develop a plan for recruiting new donors from ethnic minorities.

\section{Developing a plan}

\section{First step: Increasing blood donation from the Black communities}

The first objective in 2009 was to increase blood donation among Black communities since this particular group was underrepresented among blood donors in Quebec. At 53\% percent, Frenchspeaking Haitians make up the largest population of Blacks in Quebec (NHS 2011). In 1983, during the contaminated blood affair, Canadian health authorities asked them to voluntarily refrain from giving blood ${ }^{[42]}$. In the US, the Centers for Disease Control and Prevention (CDC) removed Haitians from the list of at-risk groups, as soon as in April 1985. In 1988, on the questionnaire used by the Canadian Red Cross, there remained an exclusion note for those who, since 1977, had lived in a region where AIDS cases were more frequent, but it did not explicitly mention Haiti. The note no longer appeared on the questionnaire in $1994^{[42]}$. As a result of this controversy, the task of recruiting blood donors from this community was a considerable challenge.

Fifty-three awareness-raising activities were organized in 2011 and 2012 , including information booths, involvement with cultural and community events, targeted presentations to different communities, discussion groups, forums with Haitian leaders, radio interviews, targeted marketing, organized tours of laboratories, and new blood drives ${ }^{[9]}$. The idea was to increase the Haitian community's awareness of sickle-cell disease, and that this disease mainly affects members of their own community. In a way, they were encouraged to give blood for the benefit of their own community members. This is different from the usual message about altruistic donation for anonymous strangers ${ }^{[4]]}$.

The number of registered donors climbed from 170 in 2009 to 1,582 in August 2012. An additional 832 donors of $\mathrm{Fy}(\mathrm{a}-\mathrm{b}-)$ phenotype blood and 22 donors of $\mathrm{U}$ negative phenotype were recorded during the same period ${ }^{[9]}$. Analyses performed using the database that compiles donor 
information (Progesa, Mak System, Paris, France) showed that while Blacks represented $10 \%$ of donors belonging to minority groups in 2011, they were nonetheless the fastest growing group among all minority donors (53\%). However, only $24 \%$ made a second donation in the same year. Moreover, associations representing the Black population expressed some reservations about recruitment campaigns that refer to Black blood as having different characteristics, even if it was done in a positive way. Associations feared that this could reignite the debate about racial differences ${ }^{[44]}$.

Despite Héma-Québec's tremendous efforts to recruit donors from the Black population, donor retention has proven difficult. But, Héma-Québec employees had a better understanding of the medical need for increased recruitment among this group more than for other ethnic group ${ }^{[8]}$. Reproducing this donor-recruitment model for other ethnic groups would simply be an overwhelming if not impossible task.

\section{Step 2: Organizing blood drives in collaboration with ethnic associations ${ }^{2}$}

In Quebec, mobile blood drives have been organized in collaboration with ethnic and/or religious associations for a number of years. Thirty-five such drives were identified in 2012-2013. Some associations defined themselves in terms of national affiliation (Lebanon, Iran, Haiti, etc.), and only one was multi-ethnic. Others were religiously affiliated (Muslim, Jewish, Adventist, Hindi, Tamil, etc.). Blood drives organized jointly with Muslim associations were the most numerous (9/35). Their leaders wished to commemorate a particular political or religious event, to counter perceived discrimination against members of their community, and saw this opportunity as a step towards their members' integration in Quebec society ${ }^{[8]}$.

Ethnic blood drives were not held in accordance with a specific development plan, given that these events were always initiated by the groups themselves. Many minorities, such as Latin Americans or Asians, were not represented as part of these blood drives. It was also difficult for Héma-Québec to determine just how effective the blood drives of these volunteer associations can be in the long term. There were several factors to consider: these events were often organized by a single individual, and the number of donors tended to be lower than average (and lower than what associations generally expect). In 2012-2013, the average number of expected donors was

\footnotetext{
${ }^{2}$ Detailed methods used in the research project are presented elsewhere: Tran and Charbonneau 2012, Charbonneau et al 2015.
} 
$78 \%$, but this average hid extreme results, such as 9 donors/40 expected or 93/75. Moreover, Héma-Québec employees did not always feel adequately prepared to work at these types of blood drives, as they explained in focus groups.

\section{Step 3: Better understanding the employees' point of view}

Meetings and focus groups with employees (2009, 2012 and 2013) indicated that working at ethnic blood drives was not highly valued by the organization. There were more donation refusals to be managed, the low number of donors brought down employee averages (quotas), and such events often required evening and weekend work. However, employees also stated that they felt warmly welcomed by ethnic associations. Their impression was that there are many religious, cultural, and social restrictions regarding blood donation. They also believed Héma-Québec needed to change many of its usual practices in order for blood drives to be in line with associations' expectations. Moreover, they thought most immigrants did not understand French well and that this explained why they did not understand the system's procedures and regulations. The employees admitted that they themselves were not familiar with such communities and associations, because they did not live in the same neighbourhoods. They also questioned the organization's motives for holding ethnic blood drives: was the blood supply insufficient, were there particular medical needs to be met, or was the objective simply to be politically correct? The reasons for recruiting donors from non-Black ethnic groups were less clear to employees. Employees said they would like to have more information so they could better greet and inform donors, and understand their questions and concerns. Above all, they wished to reduce any uneasiness and prejudices, and boost their self-confidence, as they were always afraid of committing a faux-pas.

\section{Step 4: Providing customized ethnic-diversity training to the organization's staff}

In 2013, Héma-Québec and the Research Chair decided to incorporate the information gathered during these previous initiatives, including the Chair's main research results, into a carefully tailored training program on ethnic diversity. This program had two main objectives: 1) help employees develop self-confidence in their interactions with these donors, and 2) give new tools to planning services in order to help them in their recruitment tasks. Training was provided to 69 front-line managers. It lasted two full days (incorporating several small groups), and a large amount of complementary documentation was also made available to participants ${ }^{3}$.

3 Research reports and training program PowerPoints (in French) are available at http://www.ucs.inrs.ca/chaire-don-sang. 


\section{Day One of Training}

By providing the staff members with basic information, the first part of the training aimed to help them gaining confidence before they engaged in any action involving minority groups.

The session began with a brief statistical overview of immigration in Quebec, a discussion about the growing diversity of medical needs, and the possible implications these two situations might have for the organization.

Through a combination of short group exercises and the introduction of sociological and anthropological notions, the key concepts of identity, culture, and ethnicity were presented and discussed. This enabled participants to situate themselves, and to develop confidence in their own use of the terms "immigrant population," "visible minority," "ethnic group," and "religious community." To conclude the first part of training, participants were given documents on policies regarding immigration and ethnic minorities in Canada and Quebec, intended as reference for later use.

The second part of the first day dealt directly with the issue of cross-cultural relations, as well as stereotypes, prejudices, and ethnocentrism. Participants were provided with tools to help them better manage cross-cultural exchanges. The considerable effort the organization had put into recruiting donors from Black communities in recent years has revived some old ideas about racial differences. Drawing on both anthropology and genetic research permitted to clarify the scientific status of the notion of race. It also gave the opportunity to clarify the notion of geographic origin, an important concept with regard to the compatibility necessary for treating diseases through the use of stem cells.

Lastly, a Héma-Québec representative presented corporate guidelines established by the organization in 2013 to deal with a number of cases that had arisen in recent years involving crosscultural relations.

\section{Day Two of Training}

This last discussion set the stage for the second day of training. Two separate presentations were prepared. The first was aimed at helping employees develop additional skills to improve interactions with clientele. This was especially important given the organization's challenges not 
only with donor recruitment, but also with donor retention. The second presentation, aimed at the group responsible for recruitment, focused more on providing the latter with as much information as possible to ensure optimum recruiting results.

In both instances, the day began with team exercises based on case studies. The exercises were designed both to permit participants to apply what they had learnt on the first day, and to allow them to share their expertise regarding the best ways to manage difficult situations that had taken place during blood drives in recent years.

This phase was a little shorter in workshops focused on donor recruitment. With these groups, more time was spent providing a detailed look at immigration and ethnic groups in Montreal and Quebec. An overview of immigration in Quebec and connections to be made between immigration and the presence of ethnic communities were discussed. Factors (migration policies, specific historical contexts, foreign languages, economic niches, community-specific institutions and associations, religious and cultural practices, and so forth) that have historically contributed to the creation of the main ethnic communities in Quebec were introduced. Groups also had the opportunity to work with case studies on five ethnic groups in Montreal (Black, Latin American, Arab, Chinese, and Vietnamese) produced by the Chair's team ${ }^{[8]}$. Maps were used to present the locations of current ethnic groups, the areas affected by recent migratory waves, and the locations of the principal places of worship.

The last part focused on the research findings on the motivations and behaviours of ethnic blood donors. It gave participants the opportunity to discuss the main obstacles to blood donation for different ethnic groups, as well as the key social and cultural issues regarding blood donation for these groups:

- What are different ways of defining social solidarity, charity, and altruism?

- What are the principal views on life, health, and blood cited by participants in the surveys?

- Is there any connection between blood donation and religious beliefs?

- What types of blood supply systems are immigrants familiar with before arriving in Canada?

- What are the motivations of blood donors from ethnic minorities?

- Are they different from those of donors from the majority population?

This section was concluded with a presentation on the statistical profile of donors who specified their ethnic belonging when giving blood:

- What are the largest groups?

- What percentage of donors gives blood a second time in the same year? 
- Where in Quebec do they live?

- What types of blood drives do they attend?

- Do they give at permanent blood donor centres or mobile blood drives? At universities or at community blood drives?

This information was covered quickly during the training seminar itself, but participants were also given several detailed documents for later use.

\section{Three approaches}

Lastly, three approaches for improving recruitment strategies were presented. The basic principle must be to develop strategies that will produce the best possible results while requiring the least amount of effort. The idea is to make the best choices for each group.

The objective of the first approach is not to change regular strategies in any way, but simply to count on the fact that a large part of immigrant population is Québec is well-educated. This approach takes into account the growing social diversity of large cities, but maintains the same strategies used to recruit donors from the majority population by increasing the number of blood drives in universities and large businesses where there is a highly diversified population. Immigrants who arrived in Quebec as children, those referred to as 2nd- or 3rd-generation youth, foreign students from countries with blood-supply systems similar to that of Quebec, and wellintegrated adult immigrants can be targeted by such an approach.

The objective of the second approach is taking new migratory situation into account by increasing the number of blood drives in multiethnic neighbourhoods based on criteria such as residential concentration, large immigrant waves, and so forth. This might translate into more frequent blood drives being organized in neutral non-ethnic sites, such as primary and secondary schools, or shopping centres.

The objective of the third approach is targeting groups based on major medical priorities, like the Black population. Its objective is to recruit donors from priority minorities traditionally reluctant to donate blood. To reach these groups, it is necessary to encourage the organization of drives in collaboration with volunteer associations originating in the target community. But, an effort should be made to carefully select partners, instead of waiting for them to initiate the blood drives.

At the end of the training seminar, participants were asked to carry out a strategy exercise on the spot to get them thinking about which approach would be best suited to a specific ethnic group. 
Although some elements still needed to be worked out by the end of the exercise, participants nonetheless had the opportunity to apply the various tools and use data that had been provided over the two days of training.

\section{Conclusion}

New strategies are dependent on the specific characteristics of the ethnic diversity of each country, the availability of empirical data on minorities, and the clearly expressed will of management in blood collections.

The training program's main objective-to increase the staff's confidence and level of information-was largely achieved. The post-training evaluation showed that employees were very satisfied with the experience. Thirty-six percent (25/69) of participants responded: $80 \%$ said that the training content met their needs, $100 \%$ claimed that the documentation provided to them was useful, $92 \%$ stated that the training's objectives had been achieved, and $80 \%$ said that they expected to use this new knowledge in their work. Employees also included comments stating that they perceived "this type of training to be an indispensable tool for all staff in contact with this type of clientele" and that "they were now better prepared to meet the diversity challenge." The organization considered this issue to be so important that Human Resources has now integrated key elements into the basic training provided to all employees. Since becoming directly involved through actions such as defining corporate guidelines aimed at dealing with issues stemming from cross-cultural relations during blood drives, the organization has seen a drop in the number of problem cases. The detailed study of Quebec's main ethnic communities, which examines the latter's total population, place of residence, history of immigration as well as the cultural and social implications of blood donation from their perspective, has provided relevant groundwork for the collections development strategy. It also gives the Planning Department a better ability to evaluate the associations' capacity to organize blood drives. However, since the training was offered in December 2013, it is still too soon to evaluate its success in terms of new, or more ethnically diverse, recruitment or better donor retention.

The training given in Quebec can be re-used elsewhere to a certain extent. Anything designed to help employees develop a shared vocabulary or put their heads together to come up with better ways of resolving problem situations may certainly be reproduced in other contexts. However, every country has its own policies, migration patterns, and social and cultural dynamics. Not everyone has access to as much information on immigration, ethnic minorities, and the 
characteristics of donors from these groups that could be used to establish well-targeted strategies. Blood collection services must work with their own limitations.

According to the Chair's research findings ${ }^{[8]}: 1$ ) relationships to blood (cultural attitudes, motivations, and practices) vary greatly from one ethnic group to another and, as a result, recruitment efforts must be equally diverse; 2 ) in certain cases, there is, in fact, no need to change the organization's traditional strategies; and 3) regardless of the chosen strategy, the organization's management, marketing, blood-drive planning, and customer service personnel, all need to be better informed about such groups. Success depends on ensuring staff is adequately trained, and on bolstering their self-confidence with regard to interactions with ethnic minorities.

\section{Acknowledgments}

This study was made possible by a grant from Héma-Québec.

\section{Competing Interests}

The authors declare that they have no competing interests relevant to the publication of this paper.

\section{References}

1. Duboz, P., et al., Donneurs de sang réguliers ou donneurs occasionnels : différences sociodémographiques et motivationnelles. Transfusion clinique et biologique, 2012. 19(1): p. 17-24.

2. Grossman, B., et al., Barriers and motivators to blood and cord blood donations in young African-American women. American Journal of Hematology, 2005. 78: p. 198-202.

3. Price, C.L., et al., The Sickle Cell Sabbath: a community program increases first-time blood donors in the African American faith community. Transfusion, 2009. 49: p. 519-523.

4. Shaz, B., J.C. Zimring, and D.G. Demmons, Blood donation and Blood Transfusion: Special Considerations for African Americans. Transfusion Medicine Reviews, 2008. 22(3): p. 202214.

5. Bailey, E.J., Medical anthropology and African American Health. 2000, Westport, Conn.: Bergin \& Garvey. $x, 255$ p.

6. Dyson, S.M. and K. Atkin, Sickle cell and thalassaemia: global public health issues come of age. Ethnicity \& Health, 2011. 16(4-5): p. 299-311.

7. Cloutier, M.S., et al., Regional variation in the modeling of donation frequency: the case of Héma-Québec, Canada. Transfusion, 2012. 52(11): p. 2329-38. 
8. Charbonneau, J. and N. Tran, Le don de sang et les communautés ethnoculturelles au Québec. 2014, INRS: Montreal, Canada. p. 190 pages.

9. Charbonneau, J. and S. Daigneault, Recruiting donors from ethnic minorities: A multi-step training program for blood supply agencies, in Association of Donor Recruitment Professionals. 2013.

10. Statistique Canada, Enquête nationale auprès des ménages de 2011, in 99-010-X2011026, 99-010-X2011028, 99-004-XWF au catalogue et compilation spéciale commandée par I'INRS le 24 juillet 2013. 2013, Gouvernement du Canada: Ottawa.

11. Gouvernement du Québec, Population immigrée recensée au Québec et dans les régions en 2006: caractéristiques générales. 2009, mai, Ministère de l'Immigration et des Communautés culturelles. p. 171.

12. Gouvernement du Québec, Portrait des personnes membres des minorités visibles au Québec et de leur insertion économique. Recensement de 2006. 2013, MICC, Direction de la recherche et de l'analyse prospective.

13. Glynn, S.A., et al., Factors influencing the decision to donate: racial and ethnic comparisons. Transfusion, 2006. 46(6): p. 980-990.

14. Schreiber, G.B., et al., Convenience, the bane of our existence, and other barriers to donating. Transfusion, 2006. 46(4): p. 545-553.

15. Nguyen, D.D., et al., Blood donor satisfaction and intention of future donation. Transfusion, 2008. 48: p. 742-748.

16. Steele, W.R., et al., The role of altruistic behavior, empathetic concern, and social responsibility motivation in blood donation behavior. Transfusion, 2008. 48(1): p. 43-54.

17. Shaz, B.H., et al., Demographic patterns of blood donors and donations in a large metropolitan area. Journal of the National Medical Association, 2011. 103(4): p. 351-7.

18. Brijnath, B., M.J. Polonsky, and A.M.N. Renzaho, "Je ne sais pas comment faire": évaluation des connaissances des immigrants africains établis en Australie au sujet du don de sang, in Les enjeux du don de sang dans le monde : entre altruisme et solidarités, universalisme et gestion des risques, J. Charbonneau and N. Tran, Editors. 2012, Presses de l'École des hautes études en santé publique: Rennes. p. 131-151.

19. Charbonneau, J., et al., Le don de sang. Un geste social et culturel. Sociétés, culture et santé, ed. F. Saillant. 2015, Québec: Presses de l'Université Laval. 282.

20. Hollingsworth, B. and J. Wildman, What population factors influence the decision to donate blood? Transfusion Medicine, 2004. 14(1): p. 9-12.

21. Shaz, B., et al., Demographic variations in blood donor deferrals in a major metropolitan area. Transfusion, 2009.

22. Duboz, P., G. Boëtsch, and B. Cunéo, Le don de sang des populations étrangères et d'origine étrangère à Marseilles. Santé publique, 2010. 22(4): p. 379-391.

23. Adegbembo, A.O., S.L. Tomar, and H.L. Logan, Perception of racism explains the difference between Black's and White's level of healthcare trust. Ethnicity and Disease, 2006. 16: p. 792-798. 
24. Boulware, L., et al., Understanding disparities in donor behavior: race and gender differences in willingness to donate blood and cadaveric organs. Medical Care, 2002. 40(2): p. 85-95.

25. Bussey-Jones, J., et al., The role of race and trust in tissue/blood donation for genetic research. Genetics in Medicine, 2010. 12(2): p. 116-121.

26. Davis, C. and G. Randhawa, The Influence of Religion on Organ Donation and Transplantation Among the Caribbean and Black African Population - A Pilot Study in the United Kingdom. Ethnicity and Disease, 2006. 16: p. 281285.

27. Murphy, E.L., et al., Minority and foreign-born representation among US blood donors: demographics and donation frequency for 2006. Transfusion, 2009. 49: p. 2221-2227.

28. Tran, N.Y.L., J. Charbonneau, and V. Valderrama-Benitez, Blood donation practices, motivations and beliefs in Montreal's Black communities: the modern gift under a new light. Ethnicity \& Health, 2012: p. 1-22.

29. Agbovi, K.K., et al., Etude des connaissances, attitudes et pratiques en matiere de don de sang. Enquete sociologique dans la population de Lome (Togo). Transfusion Clinique et Biologique, 2006. 13(4): p. 260-265.

30. de Coning, D., Finding blood donors: challenges facing donor recruitment in South Africa. Vox Sanguinis, 2004. 87(s2): p. 168-171.

31. Javadzadeh Shahshahani, H., et al., Knowledge, attitude and practice study about blood donation in the urban population of Yazd, Iran, 2004. Transfusion Medicine, 2006. 16(6): p. 403-409.

32. Martinez, C., L'experience d'un medecin de prelevement au Chili. Transfusion Clinique et Biologique, 2006. 13(3): p. 203-205.

33. Olaiya, M.A., et al., Knowledge, attitudes, beliefs and motivations towards blood donations among blood donors in Lagos, Nigeria. Transfusion Medicine, 2004. 14(1): p. 13-17.

34. Parmasad, V., Elle est mon sang: don de remplacement, parentalité et liens transactionnels à Trinité-et-Tobago, in Les enjeux du don de sang dans le monde : entre altruisme et solidarités, universalisme et gestion des risques, J. Charbonneau and N. Tran, Editors. 2012, Presses de l'École des hautes études en santé publique: Rennes. p. 241260.

35. Sampath, S., et al., Attitudes towards blood donation in Trinidad and Tobago. Transfusion Medicine, 2007. 17(2): p. 83-87.

36. Grassineau, D., et al., Improving minority blood donation: anthropologic approach in a migrant community. Transfusion, 2007. 47(3): p. 402-409.

37. Shaz, B., et al., The African American church as a donation site: motivations and barriers. Transfusion, 2010. 50: p. 1240-1248.

38. European Blood Alliance, MIMI Action Plan for Minority Recruitment. Working towards a diverse and representative donor population. 2013. p. 32.

39. Bouchard, G., L'interculturalisme. Un point de vue québécois. 2012, Montreal: Boréal. 
40. Charbonneau, J., Ethno-cultural Diversity and Blood Donation: A Complex Issue for Blood Product Supply Organisations, in World Blood Donor Day (UNESCO). 2013: Paris.

41. Charbonneau, J. and A. Quéniart, The influence of blood collection organizations on blood donation motivations and practices, in Giving blood: the institutional making of altruism, J. Charbonneau and A. Smith, Editors. Fourthcoming, Routledge: London.

42. Charbonneau, J.a.N.T., The paradoxical situation of blood donation in the Haitian-Quebec Community. Canadian Ethnic Studies, 2015. 47(2): p. 71-96.

43. Charbonneau, J. and N. Tran, Les enjeux du don de sang dans le monde : entre altruisme et solidarités, universalisme et gestion des risques. 2012, Rennes: Presses de l'École des hautes études en santé publique. 359 p.

44. Héma-Québec, Audit auprès de membres de la communauté haïtienne de Montréal. 2009, août, Le Cabinet de relations publiques National pour le compte d'Héma-Québec. p. 81. 